\title{
FRAUDULENT FINANCIAL REPORTING BY DISTRICT / MUNICIPAL GOVERNMENT IN INDONESIA ${ }^{1}$
}

\author{
Indra Kusuma \\ Audit Board of the Republic of Indonesia (BPK) - University of Sebelas Maret \\ indra29kusuma@gmail.com
}

Halim Dedy Perdana

Sri Suranta

University of Sebelas Maret

\section{ARTICLE INFORMATION}

Article history:

Received August 01, 2016

Revised Dec 09, 2016

Accepted May 17, 2017

\section{JEL Classifications}

M42; M48

\section{Key Words:}

Fraudulent financial reporting;

Fraud diamond;

Audit opinion;

Leverage;

Percentage of budget realization;

Income transfers;

Internal control weakness;

Previous year opinion;

Changes of regent/mayor.

\section{DOI:}

10.21532/apfj.001.17.02.01.03

\begin{abstract}
This research aims to analyze and obtain empirical evidence about the influence of fraud diamond (pressure, opportunity, rationalization, and capability) on fraudulent financial reporting in the public sector. Opinion on the financial statements of the district /municipal government in Indonesia is used as a proxy to indicate fraudulent financial reporting. The population used in this research is the district / municipal governments in Indonesia. The total samples are 437 district / municipal governments obtained through convenience sampling method. This research uses secondary data drawn from BPK's Audit Reports of 2014 and 2015 and BPK's Audit Results Summary of the First Semester (IHPS) of 2015. To analyze the data, this research uses logistic regression analysis with the SPSS 20.0 software tools. The results show that the factor of pressure, ie financial target that is proxied by percentage of budget realization has negative effect on fraudulent financial reporting; the factor of opportunity, ie related party transaction that is proxied by income transfers from the central government and internal control weakness that is proxied by audit findings of internal control systems in BPK's Audit Result Reports has positive effect on fraudulent financial reporting, ie the factor of capability that is proxied by changes of regent / mayor has positive effect on fraudulent financial reporting, while the factor of pressure, ie external pressure that is proxied by local government capability of paying its liabilities (leverage) and the factor of rationalization that is proxied by previous year non-unqualified opinion has no significant effect on fraudulent financial reporting.
\end{abstract}

1 The Winner of 2016 Call for Papers of ACFE Indonesia Chapter 


\section{INTRODUCTION}

Global economic order can never escape from a threat, called fraud. Any organization or entity should be wary of the threat. This is in line with the statement of the Association of Certified Fraud Examiner (ACFE, 2014) "Fraud is ubiquitous. It does not discriminate in its occurrence". No organization or entity has immunity to this threat. Various cases of fraud have become the headlines of both local and international media. The case is indiscriminate and may occur in either poor countries, developing countries, or developed countries. Several cases of fraud are most frequently reported to occur in private, particularly in financial and banking, sector. However, there are also some reports related to fraud occurring in government sector. This is quite ironic, because the government is supposed to be a tool for a country in enforcing the law and regulations, but some elements therein, in fact, commit fraud.

Stakeholders (the people and the legislature) always demand for accountability and transparency in state financial management by both central and local government. And these interests can be accommodated through good governance. Based on agency theory (Jensen and Meckling, 1976), agency conflict or conflict of interest can occur between the legislature (principal) and the government (agent). These differences in interests, in turn, will lead to agency problems, one of which is fraud. To ensure that the government acts in accordance with the interests of the people / the legislature requires independent and professional external auditors, namely the Supreme Audit Board of the Republic of Indonesia (hereinafter referred to as Badan Pemeriksa Keuangan or BPK).

BPK's audit results of the local government financial statements, budget year 2014, reveal that 251 local government financial statements receive unqualified opinion, 230 local government financial statements receive qualified opinion, 44 local government financial statements receive adversed opinion, and 19 local government financial statements receive disclaimer of opinion. The audit result, in the form of opinion, is obtained from a reasonable assurance that the financial statement is free of material misstatements. The local government financial statements that receive audit opinion other than unqualified opinion (non-unqualified opinion) generally have weaknesses or irregularities in their financial reporting based on the government accounting standards, one of them is in the form of material misstatement. The deliberate act causing material misstatement in the financial statements is a form of fraud. This is in accordance with the Statement of Auditing Standards (PSA) No. 70 (SA Section 316) "accounting fraud is a misstatement arising from fraudulent financial reporting". Thus, the audit opinions other than unqualified opinion (non-unqualified opinion) contain elements of fraud which, according to the Association of Certified Fraud Examiner (ACFE), is called fraudulent statements / fraudulent financial reporting.

Fraudulent financial reporting can be 
explained through Cressey's fraud triangle (1953), in Lou and Wang (2009), consisting of: 1) pressure / motive; 2) opportunity; and 3) attitude / rationalization. Wolfe and Hermanson (2004) add capability as a qualitative factor and as the complement of Cressey's fraud triangle model. This research is the development of the research conducted by Luqi Santo Timor Andriana (2015) on the factors of fraud in the financial statements of local governments in Indonesia. The difference is in the addition of the proxy of the variable of pressure, ie budget realization, and the proxy of the variable of opportunity, ie the internal control weakness.

Based on the background described above, the research question is: Do the factors of pressure, opportunity, attitude, and capability have an effect on fraudulent financial statements of district / municipal governments in Indonesia?

\section{THEORETICAL FRAMEWORK AND HYPOTHESIS DEVELOPMENT}

\section{Agency Theory}

Theory of the relationship between principal and agent has been warmly discussed by academics-practitioners in the field of social sciences and economics since the 1970s. Ross and Mitnick claim that they are the first who issue "The Theory of Agency". However, the most frequently cited reference regarding the "Agency Theory" is derived from the statement of Jensen and Meckling.

Jensen and Meckling (1976) define an agency relationship as a contract in which one person or more (as the principal) bind to another person (as the agent) to carry out activities on behalf of the principal, and the principal gives the agent some authorities to take decision. In the agency relationship, each of the parties is likely to maximize its own utility and the agent does not always act in accordance with the wishes of the principal. Therefore, the principal can limit the agency problem / conflict of interest by spending agency cost. Agency problem occurs at any levels of organization, any levels of management, universities, corporations, various forms of cooperation, and also government.

\section{Local Finances}

Local finances, such as local revenue, local spending, and local equity, are parts of the state finance as stipulated in Law No. 17 of 2003 on State Finance. The local financial management itself is set in Government Regulation (PP) No. 58 of 2005, which states that local finance is the local right and obligation to maintain the local government that can be valued in money including all forms of wealth relating to local rights and obligations of the area. The local financial management is all activities that include planning, implementation, administration, reporting, accountability, and oversight of local finances.

\section{Government Internal Control System}

Internal control system consists of policies, practices and procedures used by a company to achieve its four general objectives, namely: securing corporate assets, ensuring the accuracy and reliability of the various records 
and accounting information, disseminating efficiency in the company's operations, and measuring compliance with policies and procedures established by management (Hall and Singleton, 2009).

The Government Regulation No. 60 of 2008 on the Government Internal Control System states: "Internal control system is an integrated process of actions and activities carried out continuously by the management and all employees to provide reasonable assurance on the achievement of organizational objectives through effective and efficient activities, reliable financial reporting, security of state assets, and compliance with laws and regulations.

\section{Fraud}

According to the Association of Certified Fraud Examiners (ACFE), fraud is an act against the law done intentionally for a specific purpose (manipulating or giving false reports to the other party). The act is done by people from inside or outside the organization for personal or group's interests that are directly or indirectly harmful to other parties. ACFE divides fraud within three (3) types or typology of works, namely: asset misappropriation, fraudulent financial statements, and corruption.

\section{Fraud Diamond Theory}

Cressey (1953), in Wells (2001), explains that people who commit fraud are driven by three factors: pressure, perceived opportunity, and rationalization. According to Wolfe and Hermanson (2004,) Cressey's fraud triangle theory can be perfected to improve prevention and detection of fraud by adding the fourth element, that is, capability.

\section{Hypothesis Development}

Cons with previous studies that took the research object of private sector, the authors try to direct this research object to the public sector. The authors try to replicate the previous research by adjusting and reducing the existing proxies in the previous studies, because not all proxies are suitable if they are drawn into the public sector. Based on the theoretical basis and the previous studies, it can be arranged a systematic framework that describes the variable of fraudulent financial reporting in the public sector.

\section{Pressure: Local Government's Capability of Meeting the Liabilities (Leverage) and Achieving the Budget Realization Target}

One of the external pressures is leverage (Skousen, 2004). According to Mustafa (2003), the companies that experience fraudulent action have the higher number of liabilities than those that do not. Thus, in this research, pressure is measured using the capability of district / municipal governments to pay the liabilities (leverage).

Government budget absorption is almost the same as the financial target on the private sector in terms of percentage of achievement that should be close to the target that has been set. However, the fundamental differences in the objectives of the organization, either profit-oriented or non-profit oriented, bring 
significant differences. In private sector, fraud is generally done by way of overstating the income or understating the cost. If the company's real income is small, this shows the negative effect of financial target on fraudulent financial reporting. Companies that perform fraudulent financial reporting are indicated that the achievement of their real financial target (profitability) is low (Spathis, 2002). For the public sector in Indonesia, since its financial target is the realization of the budget, the fraud is generally performed by way of overstating the expenditures, such as fictitious spending and overpayments, whereas the number of real expenditure is low. Thus, in this study, pressure is measured by the realization of the budget.

Based on the descriptions above, the research hypothesis can be formulated as follows:

H1a: The local government's capability of paying the liabilities (leverage) has positive influence on fraudulent financial reporting

H1b: Budget expenditure absorption has negative influence on fraudulent financial reporting.

Opportunity: Related Party Transaction (Income Transfer from Central Government to Local Government) and the Weakness of Internal Control System

Related party transaction that involves the outside parties of the entity tends to be accompanied by a high inherent risk because it is usually accompanied by higher accountability requirements. Management tends to manipulate the use and the related party transaction reporting. Lou and Wang (2009) conclude that when there are many complicated transactions, such as transactions arising from complex financial schemes and related party transactions, the company will likely experience the fraud.

Research conducted by KPMG (2008) shows that the main factor that leads to fraud is a weak control system. This is consistent with KPMG's previous studies since 1993. In line with the study by KPMG, ACFE (2014) also finds that the weakness of the control system is the most common factor that contributes to fraud. According to Bell and Carcello (2000), one of the determinants of fraud is a weak internal control environment. Thus, the finding of the weakness of the internal control system is used to measure the opportunity.

Based on these descriptions, the research hypothesis can be formulated as follows.

H2a: Income transfer has positive influence on fraudulent financial reporting.

$\mathrm{H} 2 \mathrm{~b}$ : The weakness of internal control system has positive influence on fraudulent financial reporting.

\section{Rationalization: The previous years' finan- cial statements that re- ceive audit opinions other than unqualified opinion (non-unqualified opinion)}

Francis and Krishnan (1999) and Skousen and Wright (2006) state that the management's decision making process in achieving profit targets, outputs, and outcome opens the road towards the encouragement or understanding of management, which might lead to the 
rationalization to commit fraud in financial reporting. Rationalization of fraudulent financial statements is measured with the audit opinions obtained by the local government financial statements for the last 2 years which is other than unqualified opinion (non-unqualified opinion. The reason for the local government to perform fraudulent financial reporting is that it has occurred since the past, and then it becomes a rationalization / justification

Based on these descriptions, the hypothesis can be formulated as follows:

H3: Non - Unqualified Opinion on the previous year's financial statements has positive influence on fraudulent financial reporting.

\section{Capability: Changes in Local Government Head (Regent / Mayor)}

Beasley, Carcello, and Hermanson (1999) find that $83 \%$ of financial fraud involves the ChiefExecutive Officer (CEO) and / or the Chief Financial Officer (CFO). In line with this, Wolfe and Hermanson (2004) conduct a study with a focus on fraud risk factors, especially the factor of capability which becomes the background of the occurrence of fraud. The study finds that the changes in board of directors have an "indication" of fraud. Substitution of board of directors is part of the company's effort to improve the company performance doe to less efficient and effective policies of the previous director. The substitution of directors also indicates an effort of the company to eliminate the directors who are deemed to know fraud occurring in the company.
Carcello (2009) states that the financial statement containing material misstatement often occurs as a result of deliberate action of the senior managers (CEO and / or CFO) to misstate the financial results, or the management makes mistakes in preparing financial statement. The substitution of directors in the public sector (local government) is the same as the substitution of executives (Regional Head).

H4: Changes in Local Government Head have positive influence on fraudulent financial reporting. 


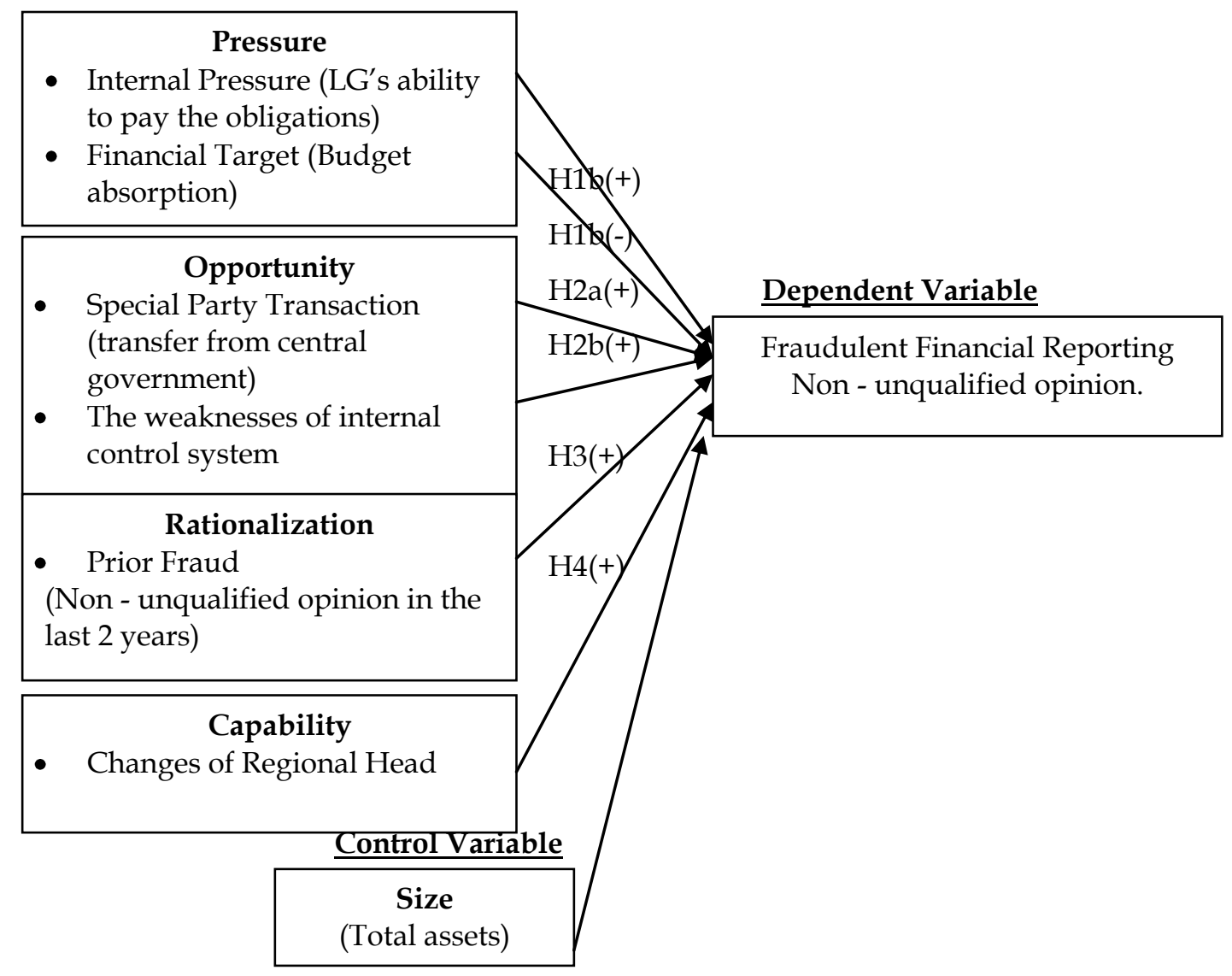

\section{Research Method}

The population used in this study is all district / municipal governments in Indonesia in 2014. The research samples are obtained using a convenience sampling method in which the data are obtained from the samples which are most readily available, such as BPK's Audit Reports of 2014 and BPK's Audit Report Summary of the First Semester of 2015, with the criteria of the entities that are required to prepare financial statements in 2013 and 2104, and the data of the sample that can be obtained.

This study uses secondary data, with the reason that the data have had validity guaranteed by other parties so as to be reliable for the research. The data collection method used in this study is documentation method, in which the data collection is done by studying the company's records or documents in accordance with the data needed. The data used are the local government financial statements fiscal year 2013 and 2014 taken from the BPK's Audit Reports of 2014 and BPK's Audit Report Summary of the First Semester of 2015.

This study uses two main variables, namely independent variables and dependent variable, and control variable. The independent variable in this study is the factors of fraud according to Diamond Fraud (Fraud Triangle + Capability) developed from the research of Skousen et al. (2008), Kennedy Samuel Sihombing and Rahardjo (2014) and Luqi Santo Timor Andriana 
(2015), namely: a) external pressure which is proxied by the ratio of local governments' capability of paying liabilities (LEVERAGE) and the percentage of budget absorption (REALEXP); b) opportunity which is proxied by related party transactions, ie between local government and central government from the total income transfer (LNTRANS) and internal control weaknesses (ICW); c) rationalization which is proxied by non-unqualified opinion obtained for the last two years (PRIOROP); d) capability which is proxied by the changes in Regional Head (CHKD). The dependent variable in this study is fraudulent financial reporting in district / municipal governments in Indonesia which is proxied by the opinion of BPK's Audit Reports (FFR). Measurement of fraudulent financial reporting is conducted using the dummy, where the score 1 shows that local government is suspected to perform fraudulent financial reporting with opinion other than Unqualified Opinion (non-unqualified opinion) and the score 0 is for the local governments that do not perform fraudulent financial reporting (Kurniawan Dwi Haryanto 2011 and
Luqi Santo Timor Andriana, 2015). This study uses the size of the local government which is seen from the value of total assets (LNASET) transformed through a process of logarithms as the control variable in testing the influence of several proxy variables of the factors of fraudulent financial reporting.

Statistical analysis tool used in this study is software SPSS 20.0. In searching for the relationship between the variables in this study, the researchers use logistic regression analysis, because the data used in this study are non metric (dummy) on the dependent variable (FFR), while the independent variables (LEVERAGE, REALEXP, LNTRANS, ICW, PRIOROP, and $\mathrm{CHKD)}$ are a hybrid between continuous variables (metric data) and categorical (nonmetric data). Logistic regression analysis does not require the data normality assumption and does not need to prove classical assumptions such as multicollinearity, autocorrelation, and heteroscedasticity (Imam Ghozali, 2013).

The logit models used in this study can be described as follows:

\section{$F F R=\beta 0+\beta 1 L E V E R A G E+\beta 2 R E A L E X P+\beta 3 L N T R A N S+\beta 4 I C W+\beta 5 C H O P+\beta 6$ $C H K D+\varepsilon$}

Description:

\begin{tabular}{|l|l|l|}
\hline FFR & $:$ & $\begin{array}{l}\text { Dummy variable by encoding: } \\
- \text { "1" for Opinion other than Unqualified Opinion, as an indication that there } \\
\text { is fraud } \\
- \text { " } 0 \text { " for Unqualified Opinion }\end{array}$ \\
\hline LEVERAGE & $:$ & The ratio of total liabilities to total assets \\
\hline REALEXP & $:$ & The percentage of budget absorption \\
\hline LNTRANS & $:$ & The amount of income from transfer (log natural (Ln)) \\
\hline
\end{tabular}




\begin{tabular}{|l|l|l|}
\hline ICW & $:$ & $\begin{array}{l}\text { Dummy variable, code } 1 \text { is when there is a weakness in internal control } \\
\text { system, and code } 0 \text { is when there is no.. }\end{array}$ \\
\hline PRIOROP & $:$ & $\begin{array}{l}\text { Dummy variable, code } 1 \text { is when the local government receives Unqualified } \\
\text { Opinion in the last } 2 \text { years, code } 2 \text { is when the local government got audit } \\
\text { opinion other than Unqualified Opinion for the last } 2 \text { years, and code } 0 \text { is } \\
\text { when the local government did not get. }\end{array}$ \\
\hline$C H K D$ & $:$ & $\begin{array}{l}\text { Dummy variable, code } 1 \text { is when there is LG head substitution in the last two } \\
\text { years, code } 0 \text { is when there is no LG head. }\end{array}$ \\
\hline
\end{tabular}

\section{DATA ANALYSIS AND DISCUSSION}

\section{Description of the Data}

This study uses secondary data from Local Government Financial Statements of 2013 and 2014 that have been audited by BPK, and data of BPK's Audit Report Summary of the First Semester of 2015. The population in this study is all district / municipal governments in Indonesia, as many as 505 entities that are required to prepare financial statements. The sampling process is done by using a convenience sampling method.

Of the 505 reporting entities, the researchers can obtain a sample of 430 observations. Three data / observations are indicated as outliers (*residual case wise diagnostics, outliers outside "2" standard deviations") because the data deviate too far from the other data (extreme data). The variables that have extreme values can distort the regression coefficient estimates. Therefore, the extreme-value data (outlier) need to be excluded from the research data with case wise diagnostics so that the observations, that become the final sample, are as many as 427 district / municipal governments.

\section{Descriptive Statistics}

Descriptive statistics test in this study aims to provide a general overview of the characteristics of the research variables that include the number of observations $(\mathrm{N})$, the mean value, the maximum value, the minimum value, and the standard deviation value which describe the propagation of data.

Table1

\section{Descriptive Statistics}

\begin{tabular}{lcrrrr}
\hline & $\mathrm{N}$ & Minimum & Maximum & \multicolumn{1}{c}{ Mean } & Std. Deviation \\
\hline FFR & 427 & 0 & 1 & 0.5363 & 0.4993 \\
LEVERAGE & 427 & 0.0000 & 0.0796 & 0.0079 & 0.0118 \\
REALEXP & 427 & 67.0000 & 98.6500 & 87.9794 & 5.1838 \\
LNTRANS & 427 & 26.5982 & 29.3911 & 27.5458 & 0.4699 \\
ICWCASE & 427 & 1 & 32 & 11.0820 & 4.9267 \\
PRIOROP & 427 & 0 & 1 & 0.7377 & 0.4404 \\
CHKD & 427 & 0 & 1 & 0.2740 & 0.4465 \\
LNASET & 427 & 27.1880 & 31.2844 & 28.5026 & 0.6449 \\
\hline
\end{tabular}

Source: Processed Secondary Data 
The results of descriptive statistics in Table 1 show that the number of samples in the study is 427 observations. The variable of fraudulent financial reporting (FFR) is a dummy variable that has a minimum value of 0 and a maximum value of 1 with a mean value of 0.5363 . This indicates that as many as $53.63 \%$ or 229 district / municipal governments get unqualified opinion, while the remaining $51.46 \%$ or 198 district / municipal governments get audit opinion other than unqualified opinion (nonunqualified opinion) indicating that they perform fraudulent financial reporting.

The variable of government's capability of paying liabilities (LEVERAGE) has a minimum value of 0.0000 and a maximum value of 0.0796 with a mean value of 0.0079 . This shows that the average ratio of obligation to the district / municipal government's assets is small, or below $1 \%$. The smaller the leverage ratio, the smaller the obligation of the district / municipal government, and the smaller the risk of failure to restore the obligations.

The variable of budget expenditure realization (REALEXP) has a minimum value of 67.0000 and a maximum value of 98.6500 with a mean value of 87.9794 . It shows that the expenditure realization of district / municipal government has a minimum value of $67.00 \%$ and a maximum value of $98.65 \%$. The expenditure realization of district / municipal government has the mean value of $87.98 \%$, which means that the district / municipal government attempts to achieve the budget realization target of $100 \%$.
The variable of Income Transfer (LNTRANS) which is measured by the natural $\log (\mathrm{ln})$ has a minimum value of 26.5982 and a maximum value of 29.3911 with a mean value of 27.5458. Subulussalam municipal government obtains the smallest income transfer, or as much as IDR 355,995,386,095.24, conversely Kutai district government obtains the biggest income transfer as much as 5,813,145,104,038.00. The amount of income transfer is expected to help achieving the goals of the nation and state, among other things is to encourage economic growth in the area.

The variable of previous year opinion (PRIOROP) has a minimum value of 0 and a maximum value of 1 with a mean value of 0.7377 . This indicates that $26.23 \%$ or as many as 112 district / municipal governments get unqualified opinion in the last 2 years, while the remaining $73.77 \%$ or 315 district / municipal governments get audit opinion other than unqualified opinion in the last 2 years.

The variable of Changes in Regional Head (CHKD) has a minimum value of 0 and a maximum value of 1 with a mean value of 0.2740 . This indicates that $27.40 \%$ or as many as 117 district / municipal governments experience regional head substitution in the last 2 years, while the remaining $72.6 \%$ or 310 district / municipal governments do not experience regional head substitution in the last 2 years.

ThevariableofTotalAssetswhichismeasured by the $\log$ natural $(\ln )$ has a minimum value of 27.1880 and a maximum value of 31.2844 with a mean value of 28.5026. Pulau Morotai district 
government has the smallest total assets, or IDR 642,093,117,216.92, conversely Surabaya municipal government has the biggest total assets, or $38,605,937,665,339.50$. The district / municipal governments that have great assets are the long-standing areas and tend not as the result of the expansion and identical to the big city.

\section{Hypothesis Test}

Overall Fit Model Test

Likelihood (L) Test

Table 2

Likelihood (L) Test

\begin{tabular}{cc}
\hline Block & -2 Log likelihood \\
\hline 0 & 589.695 \\
1 & 316.606 \\
\hline
\end{tabular}

Source: Processed Secondary Data

Based on table 2, it can be seen that the value -2 Log Likelihood in Block 0, where the model only includes constants without independent variable, is 589.695. Meanwhile, the value -2 Log Likelihood in Block 1, where the model includes constants and independent variables in the iteration history table, downs to 316.606. The value -2 Log Likelihood in Block $0>-2$ Log Likelihood in block 1 means that the model is said to be getting better, or in other words, the addition of independent variables in the model is able to repair the model. So it can be said that the regression model in this study already fits or according to the data.
Nagelkerke $R^{2}$ Test

Table 3

Nagelkerke $R^{2}$ Test

\begin{tabular}{cccc}
\hline Step & $\begin{array}{c}-2 \text { Log } \\
\text { likelihood }\end{array}$ & $\begin{array}{c}\text { Cox \& Snell } R \\
\text { Square }\end{array}$ & $\begin{array}{c}\text { Nagelkerke } R \\
\text { Square }\end{array}$ \\
\hline 1 & $316.606 \mathrm{a}$ & 0.472 & 0.631 \\
\hline
\end{tabular}

Source: Processed Secondary Data

As described in the previous chapter, the value of Nagelkerke $\mathrm{R}^{2}$ in logistic regression can be equated to the value of $\mathrm{R}^{2}$ in the multiple linear regression to show how much the determination coefficient. Based on Table 3 , the value of Nagelkerke $\mathrm{R}^{2}$ is 0.631 which means that the independent variables are able to explain the dependent variable of $63.1 \%$ and the remaining $36.9 \%$ is explained by other variables outside the model.

Hosmer and LemeshowGoodness of fit Test

Table 4

\begin{tabular}{cccc}
\hline \multicolumn{4}{c}{ Hosmer and Lemeshow Test } \\
\hline Step & Chi-square & $d f$ & Sig. \\
1 & 9.190 & 8 & 0.327 \\
\hline
\end{tabular}

Source: Processed Secondary Data

Based on Table 4, it can be seen that Hosmer and Lemeshow Goodness of fit test produces chi-square value of 9.190 with a significance value of 0.327 . The significance value is greater than $\alpha=0.10$, which means that the model is able to predict its observation value or it can be said that the model is acceptable because it fits the observation data. 
Indra K, Halim Dedy P, Sri Suranta : Fraudulent financial reporting by district/municipal .....

Page 27-48

Accuracy Test of Model Classification

Table 5

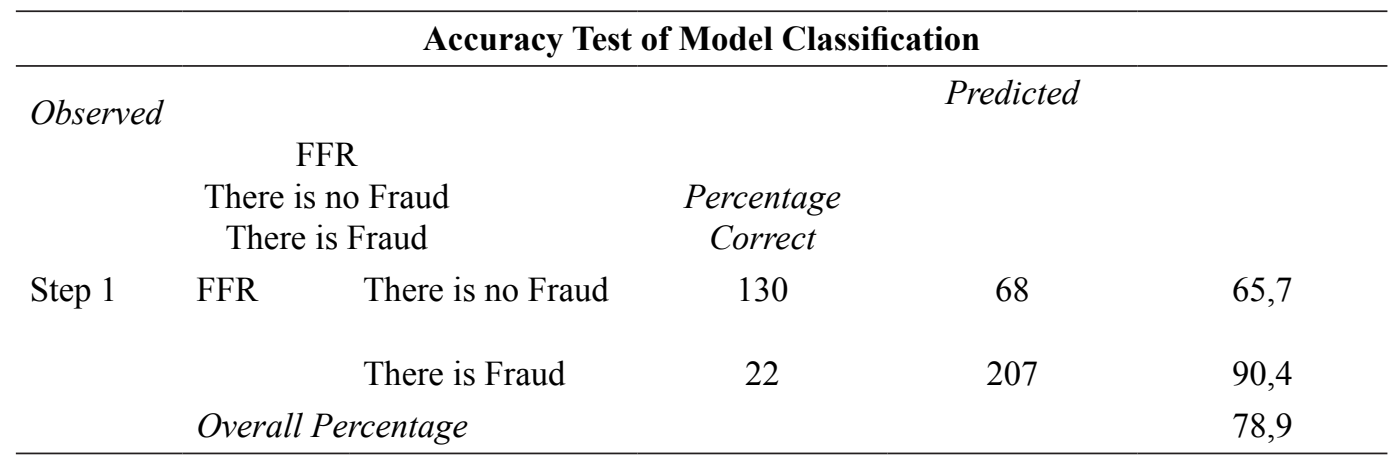

Source: Processed Secondary Data

Table 5 above shows that according to predictions, the number of district / municipal governments that do not perform fraudulent financial reporting are 198, while according to the observation result the number is only 130 , so the classification accuracy is $65.7 \%$ (130/198). According to the further predictions, the number of district / municipal governments that perform fraudulent financial reporting is 229, while according to the observation result the number is only 207, so the classification accuracy is $90.4 \%$ (207/229). Based on the two prediction results, in overall, the classification accuracy is $78.9 \%$, in which the value is more than or equal to $50 \%$, which means that this model has good prediction ability.

Simultaneous Significance Test

Table 6

\begin{tabular}{llccc}
\hline \multicolumn{5}{c}{ Omnibus Tests of Model Coefficients } \\
\hline \multirow{4}{*}{ Step } & Chi-square & $d f$ & & Sig. \\
1 & Step & 273,089 & 7 & 0,000 \\
& Block & 273,089 & 7 & 0,000 \\
& Model & 273,089 & 7 & 0,000 \\
\hline
\end{tabular}

Source: Processed Secondary Data
The test results in table 6 show that the chi-square value of 273.089 is the difference between block 0 and block 1 , while the value of chi square table with df: 7 with $\alpha$ : 0.10 is 12.017. The value of chi square count / statistics is greater than the value of chi square table, and the significance value of 0.000 is smaller than 0.10 indicating that the independent variables simultaneously affect the dependent variable. 
Individual Parameters Significance Test

Table 7

\begin{tabular}{|c|c|c|c|c|c|c|c|}
\hline \multicolumn{8}{|c|}{ Variables in the Equation } \\
\hline \multirow[b]{2}{*}{ Step $1^{\circ}$} & & $B$ & S.E. & Wald & $d f$ & Sig. & $\operatorname{Exp}(B)$ \\
\hline & LEVERAGE & -8.772 & 10.585 & 0.687 & 1 & 0.407 & 0.000 \\
\hline & REALEXP & -0.078 & 0.031 & 6.483 & 1 & $0.011^{*}$ & 0.925 \\
\hline & LNTRANS & 1.217 & 0.571 & 4.535 & 1 & $0.033^{*}$ & 3.376 \\
\hline & ICWCASE & 0.199 & 0.038 & 27.989 & 1 & $0.000 *$ & 1.220 \\
\hline & PRIOROP(1) & -22.267 & $3,616.253$ & 0.000 & 1 & 0.995 & 0.000 \\
\hline & CHKD(1) & -0.533 & 0.318 & 2.801 & 1 & $0.094 * *$ & 0.587 \\
\hline & LNASET & -0.928 & 0.446 & 4.336 & 1 & $0.037 *$ & 0.395 \\
\hline & Constant & -0.856 & 9.038 & 0.009 & 1 & 0.925 & 0.425 \\
\hline
\end{tabular}

$*$ Significance $\alpha=5 \%$

$* *$ Significance $\alpha=10 \%$

Source: Processed Secondary Data

The test results in Table 7 show that the variable of the ratio of local governments' capability of paying liabilities (LEVERAGE) and the variable of financial statement audit opinions other than Unqualified Opinion (non-unqualified opinion in the previous year (PRIOROP) have significance values above $\alpha$ $=10 \%$, which means that these variables do not affect the variable of fraudulent financial reporting (FFR). Instead, the variable of budget expenditure realization (REALEXP), the variable of related transaction / income transfer (LNTRANS), the variable of internal control weaknesses (ICWCASE), the variable of changes in regional head (CHKD) and the variable of total assets (LNASET) have significance values below $\alpha=10 \%$, meaning that these variables affect the variable of fraudulent financial reporting (FFR). But since the variable of changes in regional head (CHKD) has a negative direction, it is not consistent with the hypothesis. Thus, the variables that affect the dependent variable and in line with the direction of the relationship in the hypothesis are the variable of budget expenditure realization (REALEXP), the variable of income transfer (LNTRANS), and the variable of internal control weaknesses (ICWCASE). 


\section{DISCUSSION}

The factor of pressure in fraudulent financial reporting (H1)

\section{The local government's capability of paying} its liabilities (leverage) in fraudulent financial reporting (H1a)

Individual parameter significance test results in Table 7 show that the wald value of the variable of local government's capability of meeting its liabilities (LEVERAGE) is -8.772 with a significance value of 0.407 . The significance value which is greater than 0.10 means that H1a is rejected, so it can be said that the variable of leverage has no positive effect on fraudulent financial reporting.

Liabilities are debts arising from the past event in which its settlement results in the outflow of government's economic resources. The liabilities of district / municipal government in general arise from transaction debts of local government working unit (hereinafter referred to as SKPD) and transaction debts of local public service agencies (hereinafter referred to as BLUD). Since SKPD and BLUD are part of the reporting entity of the district / municipal government, the pressure perceived by the district / municipal government is minimal. However, if the liabilities are derived from debt agencies, which usually require detailed debt management accountability, the government could perform fraudulent financial reporting as a result of the pressure for the accountability.

This study is in line with the research conducted by Skousen (2004) where the leverage does not affect the fraudulent financial reporting. The results of this study also support the results of the research conducted by Suyanto (2009) and Fira Fimanaya and Syafruddin (2014), in which the higher the loan, the greater the operational funds, and thus results in an increase in production and sales. In increase in production and sales will also increase the profits and the pressure for management is lowering. Finally, fraud is minimized. Associated with the public sector, the increased liability for the operational activities means that the funds are avelable for public services and the performance increases, so the pressure to commit fraud to be minimal.

The results of this study are not consistent with the research conducted by Luqi Santo Timor Andriana (2015) with the same research object, ie the district / municipal government, but in different sample year, ie local government financial statements (LKPD) 2012 and 2013, where leverage has positive effect on fraudulent financial reporting. In those years the local governments were looking for other funding sources to support their operations. To maintain the leverage ratio at a reasonable level, the governments were experiencing pressure and commit fraudulent financial reporting by increasing the value of assets.

\section{Budget absorption in fraudulent financial re- porting (H1b)}

Individual parameter significance test results in Table 7 show that $\beta$ negative coefficient value is -0.078 , wald value for the variable of budget absorption is 6.483 with a significance value of 0.011 . The significance value less than 
0.10 means that H1b is received. So it can be said that the variable of budget absorption (REALEXP) has negative effect on fraudulent financial reporting.

Budget expenditure absorption is a scourge for the district / municipal governments. The governments are required to absorb the budget as much as possible, because in Indonesia, government expenditure is a driving force of economic growth, in addition to public consumption, investment and net exports. Personnel expenditure, goods / services expenditure, and capital expenditures will have multiplier effects on the economy.

The pressure of budget expenditure absorption has encouraged the local governments to implement all activities that have been planned in the local budget, but in reality, this rarely occurs because of various constraints and resource limitations. One of the local governments' efforts to raise budget expenditure realization is by performing expenditure overstatement, such as fictitious expenditure and / or overpayment. At present, overpayment is the most common case, and the case of fictitious expenditures has decreased. The district / municipal governments with low real expenditure tend to perform fraud. Thus, the budget absorption has negative effect on fraudulent financial reporting. The results support the results of the research conducted by Suyanto (2009), Fira Fimanaya and Syafruddin (2014) and Noval Dwi Aditya Nugraha and Henny (2015) that financial target has negative effect on fraudulent financial reporting.
The Factor of Opportunity in fraudulent financial reporting $(\mathrm{H} 2)$

Transactions of Special party (income transfers from central government to local governments) in the fraudulent financial reporting) (H2a)

Individual parameter significance test results in Table 7 show that the $\beta$ positive coefficient value is 1.217 , wald value for the variable of related party transactions / income transfer (LNTRANS) is 4.535 with a significance value of 0.033 . The significance value less than 0.10 means that $\mathrm{H} 2 \mathrm{a}$ is received. So, it can be said that the variable of related party transactions / income transfer has positive effect on fraudulent financial reporting.

The results support the results of the research conducted by Lou and Wang (2009), and Ema Kurniawati (2012) stating that related party transactions affect the fraudulent financial reporting. According to Beasley, Carcello, Hermanson, and Neal (2010), the companies which are indicated to have committed fraud tend to perform more frequent / larger special party transaction. The presence of this transaction increases the risk of fraud.

Most district / municipal governments rely on income transfers from the central government because the local revenue is small. This dependence indirectly forces the district / municipal governments to manipulate their financial and operational performance reports so that the the amount of the income transfer received will not decrease but increase. 
Indra K, Halim Dedy P, Sri Suranta : Fraudulent financial reporting by district/municipal .....

Page 27-48

Providing unreal / fictitious report is part of fraud.

The results of this study are not in line with the results of the study conducted by Santo Luqi Timor Andriana (2015) that the income transfer does not have positive influence on fraudulent financial reporting, because almost all get the opportunity to receive income transfers. The opportunity is in fact not the same with regard to the nominal amount of the transfer. As there are formulations of determining the number of transfers, the income transfer received by the district / municipal government is different from one another, and the central government also implements reward and punishment for the use of transfer funds so that there could be addition or reduction of funds.

\section{Internal control weakness in fraudulent financial reporting (H2b)}

Individual parameter significance test results in Table 7 show that the value of the $\beta$ negative coefficient value is 0,199 , wald value for the variable of internal control weaknesses (ICWCASE) is 27.989 with a significance value of 0.000 . The significance value less than 0.10 means that $\mathbf{H} 2 \mathrm{~b}$ is received. So, it can be said that the variable of internal control weakness has significant positive influence on fraudulent financial reporting.

The results of this study are in line with the results of the study conducted by Bell and Carcello (2000), KPMG (2008), ACFE (2014) that conclude that one of the determining factors for the occurrence of fraud is a weak internal control environment. The results of this study are also consistent with the results of the study conducted by Aditya Pramudita (2013) and Rangga Nuh Apriadi and Fachriyah (2015) that the effectiveness of internal control system of employees in an agency can prevent the occurance of fraud in the government sector.

Internal control weaknesses are characterized by many findings in BPK's Audit Results on the internal control system. The findings of the weaknesses of internal control system which contain material misstatements become an exception in qualified opinion on local government financial statements. Based on BPK's Audit Reports Summary of the First Semester of 2015, the findings of the weaknesses of internal control system are broadly grouped into the weaknesses of accounting and reporting control systems, the weaknesses of budget (revenue and expenditure) implementation control system, and the weakness of the internal control structure. The weaknesses of internal control system are found almost in all local governments.

\section{Factor of Rationalization (Non-Unqualified} Opinion in the previous year) in fraudulent financial reporting (H3)

Individual parameter significance test results in Table 7 show that the wald value for the variable of Non-Unqualified Opinion in previous (PRIOROP) is 0.000 with a significance value of 0.995 . The significance value is greater than 0.10 , which means that $\mathbf{H 3}$ is rejected. So, it can be said that the variable of Non-Unqualified Opinion in the previous year has no positive effect on fraudulent financial reporting. 
The results of this research are in line with the results of the research conducted by Fira Fimanaya and Syafruddin (2014) and Luqi Santo Timor Andriana (2015) that the previous year audit opinion has no affect fraudulent financial reporting. Cressey (1953) and Carcello and Hermanson (2008) state that interview with perpetrators of fraud is the best / ideal way to find a rationalization / justification for fraud.

Factor of capability (changes of regional heads) in fraudulent financial reporting $(\mathrm{H} 4)$

Individual parameter significance test results in Table 7 show that the $\beta$ negatif coefficient value is -0.533 , wald value for the variable of changes of regional head is 2,801 with significance value of 0.094 . The significance value less than 0.10 but the direction is negative means that $\mathrm{H} 4$ is rejected. So, it can be said that the variable of changes of regional head (CHKD) has no positive effect on fraudulent financial reporting.

The results of this research are in line with the research conducted by Kennedy Samuel Sihombing and Rahardjo (2014) that the capability has no positive influence on fraudulent Financial Reporting. According to Kennedy Samuel Sihombing and Rahardjo (2014), citing Wolfe and Hermanson (2009), it can happen if the top stakeholders want the performance improvement by recruiting the ranks of employees who are considered more competent than the previous directors. Changes of regional heads in 2013-2014 were generally due to expire term of office, not for alleged fraud. Regional head substitution is expected to improve the performance of governance and financial management. It is expected that the longer served the more increased the performance of the government because they already know the problem and the best solution.

\section{Control variable (total assets) in fraudulent financial reporting}

Individual parameter significance test results in Table 7 show that the $\beta$ positif coefficient value is -0.928 , wald value for the variable of total assets is 4.336 with a significance value of 0.037 . The significance value less than 0.10 means the variable of total assets (LNASET) has negative effect on fraudulent financial reporting.

The greater the assets of a district / municipal government, the lower the possibility of performing fraudulent financial reporting. This occurs because the local governments which have great assets are the long standing local government, not as a result of expansion so that they have experience in managing the regional finances.

\section{CONCLUSION, LIMITATION, AND SUGGESTION}

From the results of this study, it can be concluded that the factor of pressure (financial targets proxied by the percentage of budget absorption) has negative effect on fraudulent financial reporting; the factor of opportunity (related party transactions proxied by income transfers from the central government and internal control weakness proxied by the 
SPI findings LHP BPK) has positive effect on fraudulent financial reporting; the factor of capability proxied by the regional head substitution has positive effect on fraudulent financial reporting. Meanwhile, the factor of pressure (external pressure proxied by the ratio of local governments' ability to meet liabilities (leverage) and the factor of rationalization proxied by Non-Unqualified Opinion in the previous year have no affect the fraudulent financial reporting.

The limitations of this research are that this research only uses secondary data from BPK's Audit Reports and Semester Audit Report Summary in which for the factor of rationalization is less able to explain the relationship / influence on fraudulent financial reporting. Therefore, it requires additional data from the questionnaire. The use of only secondary data from a single source, BPK, limits the number / type of proxies that can be used to explain the variables.

Knowing the limitations of this study, it is suggested that: 1) future studies incorporate between the secondary data and the primary data obtained through questionnaires to enhance the research; 2) future studies extend the research sample in time series ie 5 years; 3 ) future studies use data from other sources such as the ministry of internal affairs, the ministry of finance, and the Central Bureau of Statistics (BPS) to add a proxy so as to strengthen the explanation of variables; 4) this study can be used as input for the agency as well as the auditor in creating transparent and accountable state / regional financial management.

\section{REFERENCES}

Aditya Pramudita, 2013, Faktor-Faktor Yang Mempengaruhi Terjadinya Fraud di Sektor Pemerintahan (Persepsi Pegawai pada Dinas Se-Kota Salatiga),Skripsi: Jurusan Akuntansi Fakultas Ekonomi Universitas Negeri Semarang.

Albrecht,WS, AlbrechtCO, AlbrechtCC dan ZimbelmanMF,2012, Fraud Examination, Fourth Edition,Cengage Learning Cengage Learning,South-Western.

American Institute of Certified Public Accountants (AICPA), 2007, AU Section 316: Consideration of Fraud in a Financial Statement Audit(Revised, April 2007), AICPA,USA.

American Institute of Certified Public Accountants (AICPA),2015, AU-C Section 550: Related Parties, AICPA, USA.

Amrizal, 2004, Pencegahan dan Pendeteksian Kecurangan Oleh Internal Auditor.

Annisa Fitrianadan Z Baridwan, 2012, Perilaku Kecurangan Akademik Mahasiswa Akuntansi: Dimensi Fraud Triangle,Jurnal Akuntansi Multiparadigma (Jamal), vol.3,no. 2,hal.161-331, Malang, ISSN 2086-7603. Association of Certified Fraud Examiners (ACFE),2014, Report To The Nations on Occupational Fraud and Abuse, ACFE Inc, USA.

Badan Pemeriksa Keuangan Republik Indonesia (BPK RI),2010, Seri Panduan 
Pemeriksaan "Mengenal Fraud \& GejalaGejalanya", Direktorat Litbang.

Beasley,MS, Carcello JV, dan Hermanson DR,1999, Fraudulent Financial Reporting: 1987-1997, The Committee of Sponsoring Organizations of the Treadway Commission (COSO).

Beasley,MS, Carcello JV, Hermanson DR, dan Neal TL,2010, Fraudulent Financial Reporting: 1998-2007, The Committee of Sponsoring Organizations of the Treadway Commission (COSO).

Bell, TB dan Carcello JV, 2000, A decision Aid For Assessing The Likelihood of Fraudulent Financial Reporting, A Journal of Practice and Theory, vol. 19,no. 1.

Bologna,J, Lindquist RJ dan Wells JT,1993, The accountant's handbook of fraud and commercial crime, Wiley, UK.

Carcello, JV, dan Hermanson DR, 2008, Fraudulent Financial Reporting: How Do We Close the Knowledge Gap?,Research Studies (White Papers) of Institute for Fraud Prevention (IFP).

Carcello,JV, 2009, Governance and The Common Good,Journal of Business Ethics, vol. 89, hal.11-18.

Ema Kurniawati, 2012,Analisis FaktorFaktor Yang Mempengaruhi Financial Statement Fraud dalam Perspektif Fraud Triangle,Skripsi:Fakultas Ekonomika dan Bisnis Universitas Diponegoro, Semarang.
Fira Fimanaya dan M Syafruddin,2014, Analisis Faktor-Faktor Yang Mempengaruhi Kecurangan Laporan Keuangan (Studi Empiris pada Perusahaan Non Keuangan Yang Terdaftar di Bursa Efek Indonesia Tahun 2008-2011),Diponegoro Journal of Accounting,vol.3,no. 3, hal. 1-11, ISSN (Online): 2337-3806.

Francis, JR dan Krishnan J, 1999, Accounting Accruals and Auditor Reporting Conservatism,Contemporary Accounting Research,vol. 16,no. 1, hal. 134. CBCA Business.

Hall, JA. danSingleton T,2009, Audit Teknologi Informasi dan Assurance,Salemba Empat, Jakarta.

Hendi Yogi Prabowo, 2014,To be corrupt or not to be corrupt,Journal of Money Laundering Control,vol. 17,iss.3, pp. 306-326, http://dx.doi.org/10.1108/ JMLC-11-2013-0045.

Hou, Y,2010, The Performance of PerformanceBased Budgeting in Boom Versus Bust Years: An Analytical Framework and Survey of States, SSRN: http://ssrn.com/ abstract $=1601464$.

Ika Akbarwati, 2014,Pentingnya Penyerapan Anggaran: Sebuah Pemahamanhttps:// www.selasar.com/politik/pentingnyapenyerapan-anggaran, Diakses 1 Februari 2016.

Ikatan Akuntan Indonesia (IAI), 2001,Pernyataan Standar Auditing (PSA) No. 70 (SA Seksi 316): Pertimbangan 
Indra K, Halim Dedy P, Sri Suranta : Fraudulent financial reporting by district/municipal .....

Atas Kecurangan Dalam Audit Laporan Keuangan,IAI, Jakarta.

Imam Gozali,2013,Aplikasi Analisis Multivariate dengan Program IBM SPSS 21,Badan Penerbit Universitas Diponegoro, Semarang.

Jensen, MCdanMeckling WH, 1976, Theory of The Firm: Managerial Behavior, Agency Costs and Ownership Structure,Journal of Financial Economics 3, hal.305360,North-Holland Publishing Company, USA.

Kennedy Samuel Sihombing dan SN Rahardjo, 2014,Analisis Fraud Diamond dalam Mendeteksi Financial Statement Fraud: Studi Empiris pada Perusahaan Manufaktur Yang Terdaftar di Bursa Efek Indonesia (BEI) Tahun 2010-2012,Diponegoro Journal of Accounting,vol. 03, no.02, hal 1-12, ISSN (Online): 2337-3806.

KPMG，2009, Fraud Survey 2008,KPMG Australia, Australia.

Kurnia Kusuma Rachmawati,2014, Pengaruh Faktor-Faktor dalam Perspektif Fraud Triangle Terhadap Fraudulent Financial Reporting (Studi Kasus pada Perusahaan Berdasarkan Sanksi dari Bapepam Periode 2008-2012),Skripsi: Fakultas Ekonomika dan Bisnis Universitas Diponegoro, Semarang.

Kurniawan DwiHaryanto,2011, Karakteristik Auditee dan Perusahaan Audit Sebagai Penentu Opini Audit Qualified (Studi Empiris pada Perusahaan Manufaktur
Yang Terdaftar di Bursa Efek Indonesia),Skripsi: Fakultas Ekonomi Universitas Diponegoro, Semarang.

Lou, YI dan Wang ML,2009, Fraud Risk Factor of The Fraud Triangle Assessing The Likelihood of Fraudulent Financial Reporting,Journal of Business \& Economics Research - February, vol. 7, no. 2.

Luqi Santo Timor Andriana, 2015, FaktorFaktor Yang Mempengaruhi Kecurangan dalam Laporan Keuangan Pemerintah Kabupaten/Kota di Indonesia,Skripsi: Program Studi Akuntansi Fakultas Ekonomi dan Bisnis Universitas Sebelas Maret, Surakarta.

Mardiasmo,2002, Akuntansi Sektor Publik,Penerbit Andi, Yogyakarta.

Mitnick, BM, 2005, Origin of The Theory of Agency: An Account By One of The Theory's Originators (Rev. March 25, 2013),http://ssrn.com/abstract=1020378.

Mitnick, BM,1973, Fiduciary Rationality and Public Policy: The Theory of Agency and Some Consequences, In ProceedingsAnnual Meeting of the American Political Science Association, New Orleans, LA. http://ssrn.com/ abstract $=1020859$ or http://dx.doi. org/10.2139/ssrn.1020859

Mustafa, ST,2003, Misappropriation of Assets: A Test of SAS No. 82 Risk Factors,Dissertation:Doctor of Business Administration, Cleveland State University. 
Noval Dwi Aditya Nugraha dan D Henny, 2015, Pendeteksian Laporan Keuangan Melalui Faktor Resiko, Tekanan dan Peluang (Berdasarkan Press Release OJK 20082012), e-Journal Akuntansi Trisakti,vol. 2,no. 1, hal. $29-48$, ISSN: 2339-0832.

Rangga Nuh Apriadi danN Fachriyah, 2015,Determinan Terjadinya Fraud di Institusi Pemerintahan, Jurusan Akuntansi Fakultas Ekonomi dan Bisnis Universitas Brawijaya, Malang.

Rifqi Mirza Zulkarnain, 2012, Analisis Faktor Yang Mempengaruhi Terjadinya Fraud Pada Dinas Kota Surakarta, Jurusan Akuntansi Fakultas Ekonomi Universitas Negeri Semarang, Accounting Analysis Journal, 2 (2) (2013), ISSN 2252-6765.

Robinson, M dan Brumby J, 2005, Does Performance-Based Budgeting Work?: An Analytical Review of the Empirical Literature,Working Paper: IMF 05/210,International Monetary Fund, Washington.

Robinson, M dan Last D, 2009, ABasic Model of Performance-Based Budgeting,Technical Notes and Manuals, International Monetary Fund, Washington.

Ross, SA, 1973, The Rconomic Theory of Agency: The Principal's Problem,American Economic Review 62 (2), hal. 134-139.

Sekaran, U dan Bougie R, 2013,Research Methods for Business: A Skill-Building Approach, 6th Edition, Jhon Wiley \& Sons Ltd, UK.
Skousen, CJ, Smith KR, dan Wright CJ, 2008, Detecting and Predicting Financial Statement Fraud: The Effectiveness of The Fraud Triangle and SAS No. 99,Working paper: Utah State University, USA. http://papers.ssrn.com/sol3/papers. cfm?abstract_id=1295494.

Skousen, CJ,2004,An Empirical Investigation of The Relevance and Predictive Ability of The SAS 99 Fraud Risk Factors,Dissertation: Doctor of Philoshopy, The Oklahoma State University,USA.

Skousen, CJ, dan Wright CJ,2006,Contemporaneous Risk Factors and The Prediction of Financial Statement Fraud,Working Papers: University of Texas, USA. http://papers.ssrn.com/sol3/ papers.cfm?abstract_id=938736.

Spathis, CT, 2002,Detecting False Financial Statements Using Published Data: Some Evidence from Greece,Managerial Auditing Journal, vol. 17, iss.4, hal. 179 $-191$.

Suyanto, 2009, Fraudulent Financial Statement Evidence from Statement on Auditing Standard No. 99,Gadjah Mada International Journal of Business January-April 2009,vol. 11,no. 1, pp. $117-144$.

Urip Santoso dan YJ Pambelum, 2008, Pengaruh Penerapan Akuntansi Sektor Publik Terhadap Akuntabilitas Kinerja Instansi Pemerintah dalam Mencegah Fraud,Jurnal Administrasi Bisnis, vol. 
4,no. 1, hal. 14-33,Center for Business Studies, FISIP - Unpar, ISSN:02161249.

Wells, JT, 2001, Why Employees Commit Fraud,Journal of Accountancy 191.2, hal. 89-91, http://search.proquest. com/docview/206773009?pqorigsite $=$ gscholar.

Wolfe, DT, dan Hermanson DR,2004, The Fraud Diamond: Considering The Four Elements of Fraud, CPA Journal 74.12, hal. 38-42. 